\title{
Contemporary racism and Islamaphobia in Australia
}

\author{
Racializing religion
}

\section{KEVIN M. DUNN}

University of New South Wales

\section{NATASCHA KLOCKER}

University of New South Wales

\author{
TANYA SALABAY \\ Deakin University, Australia
}

\begin{abstract}
Contemporary anti-Muslim sentiment in Australia is reproduced through a racialization that includes well rehearsed stereotypes of Islam, perceptions of threat and inferiority, as well as fantasies that the Other (in this case Australian Muslims) do not belong, or are absent. These are not old or colour-based racisms, but they do manifest certain characteristics that allow us to conceive a racialization process in relation to Muslims. Three sets of findings show how constructions of Islam are important means through which racism is reproduced. First, public opinion surveys reveal the extent of Islamaphobia in Australia and the links between threat perception and constructions of alien-ness and Otherness. The second data set is from a content analysis of the racialized pathologies of Muslims and their spaces. The third is from an examination of the undercurrents of Islamaphobia and national cultural selectivity in the politics of responding to asylum seekers. Negative media treatment is strongly linked to antipathetic government dispositions. This negativity has material impacts upon Australian Muslims. It sponsors a more widespread Islamaphobia, (mis)informs opposition to mosque development and ever more restrictive asylum seeker policies, and lies behind arson attacks and racist violence. Ultimately, the racialization of Islam corrupts belonging and citizenship for Muslim Australians.
\end{abstract}

KEYWORDS asylum seekers $\bullet$ Islam $\bullet$ Lakemba $\bullet$ new racism $\bullet$ racialization 


\section{ISLAM, RACISM AND AUSTRALIA}

At the mid-2001 Australian Census, 281,000 Muslims were enumerated (Table 1). This is recognized as an under-count, although the extent of that under-enumeration is unclear. Nonetheless, Muslims are now at least 1.5 percent of the Australian population. The largest birthplace group among Australian Muslims is Australia (36.4\%), indicating that the Muslim presence is by no means a recent phenomenon. ${ }^{1}$ Table 1 also indicates the original sources of Muslim migrants. The two major source countries between 1970 and 1990 were Lebanon and Turkey. More recent migration sources have included countries of the Indian sub-continent, Iran and Iraq, and re-established flows from Bosnia and Afghanistan. Table 1 also shows that countries in the Pacific and south-east Asia are important source areas of Australian Muslims (e.g. Fiji, Indonesia, Malaysia and Singapore). Australian Islam is very ethnically diverse, and Muslims have come to Australia in different eras under various categories of migration (refugee, family migrant, assisted passage, skilled immigrant). Like Muslims in other western nations (e.g. the UK, see Peach, 2006), their settlement experiences have been diverse, with varied degrees of socioeconomic well-being, both across and within ancestry groups. As in the UK (Hopkins, 2004: 268-9), the way that Islam is practised also varies dramatically in Australia (Dunn, 2004). This variation is sustained by the local bases of mosque organization, as well as the specific socioeconomic and cultural contexts in which Australian Muslims reside. This diversity and varied experience is poorly acknowledged in the popular discourses about Islam in Australia.

On the 30 July 2003, the Land and Environment Court in New South Wales (NSW) ruled in favour of an Islamic group's proposal to construct a prayer centre at the rural fringe of north-western Sydney, in Annangrove. The Islamic group had appealed to the court following a development rejection by the municipal authority, Baulkham Hills Shire Council. The Municipal Council's refusal was a research touchstone and is a neat example of the racialization of Australian Muslims. Kobayashi and Peake (2000: 393) define racialization as the process by which groups 'are identified, given stereotypical characteristics, and coerced into specific living conditions', they add that this often involves 'social/spatial segregation' or otherwise 'racialized places'. This process need not operate through supposed racial differentiation (genetics, skin colour, etc), but can also operate through asserted cultural features, such as religious performances. Following the court ruling, mosque opponents in Baulkham Hills were at pains to point out that they were not racists, and that they had never used the word 'race' in their campaign. Formal opposition to the mosque never drew upon themes of racial supremacy or racial separatism. References to biological 'race' were absent and there was little explicit evidence of 'colour 
Table 1 Muslims by birthplace, Australia, 2001

\begin{tabular}{|c|c|c|}
\hline Birthplace & Australian Muslims & Percentage all Muslims \\
\hline Australia & 102566 & 36.43 \\
\hline Afghanistan & 9923 & 3.52 \\
\hline Bangladesh & 7596 & 2.70 \\
\hline Bosnia \& Herzegovina & 9892 & 3.51 \\
\hline Cyprus & 3708 & 1.32 \\
\hline Egypt & 3061 & 1.09 \\
\hline Fiji & 5772 & 2.05 \\
\hline India & 2819 & 1.00 \\
\hline Indonesia & 8087 & 2.87 \\
\hline Iran & 6353 & 2.26 \\
\hline Iraq & 7749 & 2.75 \\
\hline Jordan & 1348 & 0.48 \\
\hline Kuwait & 1610 & 0.57 \\
\hline Lebanon & 29321 & 10.41 \\
\hline Malaysia & 2975 & 1.06 \\
\hline North-West Europe & 2668 & 0.95 \\
\hline Pakistan & 9238 & 3.28 \\
\hline Singapore & 2091 & 0.74 \\
\hline Somalia & 3585 & 1.27 \\
\hline Syria & 2261 & 0.80 \\
\hline Turkey & 23479 & 8.34 \\
\hline Sub-total & 246102 & 87.4 \\
\hline All & 281576 & \\
\hline
\end{tabular}

Source: Australian Bureau of Statistics, 2003.

racism' (Modood, 2005: 6-7). However, that does not mean that racism was absent. ${ }^{2}$ The case showed the grounded operation of dominant discourses about Islam. These constructions of Otherness (incivility, inferiority and incompatibility in the above case) are key tools of contemporary racism in Australia.

The above dispute could ably demonstrate what has been called the 'new racism' (Barker, 1981; Cole, 1997; Gilroy, 1987; Hall, 1992: 256-8; Jayasuriya, 2002). This is a form of racism where individual (and group) 
rights are confined on the basis that a cultural group's ways of life are judged as nefarious, or on the basis that a cultural group does not fit or belong within the society as defined by a protagonist. These racisms depend heavily upon discourses of Otherness, but as we demonstrate in this article, they also utilize discourses of inferiority. However, 'new racism' presumes a meaningful departure from 'old' biological racism. As we show in this article, the contemporary racialization of Islam in Australia actually has a great deal in common with old racism. This equivalence exceeds the degree of conceptual separation between 'old' and 'new' racisms to the extent that the old and new division may be misleading. Modood (2005) prefers to distinguish between 'colour racism' and 'cultural racism' so as to provide a more tangible distinction between forms of racism. Our stance is to acknowledge this variation, but to also emphasize how the two logics of racism exist side by side, and furthermore, that they are both reproduced through a similar racialization process. We offer four comments on the similarities between old and new racisms, and these comments also apply to colour racism and cultural racism. In general, our argument conceives anti-Islamic racism as a racialization, based not on some supposed biological grounds, but on religion and culture (including appearance) more generally (see Hopkins, 2004: 257-9).

First, much like the old racism (e.g. notions of racial supremacy and separatism), the new racisms operate to reinforce cultural privilege (see Hubbard, 2005). This racism is not necessarily subtle, as suggested by some definitions of new racism. New racisms still fundamentally assist with structures of inferiority (hierarchies) and differentiation (exclusion). A second overlap regards the reliance upon generalizations, or inherentisms (after Blum, 2002), that are the bases of stereotyping. To judge a culture as inferior or alien requires an a priori assertion that the racialized group has a cultural core, a uniform and static way of life that can be judged as lacking (Modood, 2005: 13-14). To assert such a shared cultural inferiority is little different from asserting a shared biological inferiority. Indeed, the reference to indelible and unbridgeable differences for racist purposes, using for example religious difference, long predated the development of scientific racisms and notions of biological difference (Fredrickson, 2002: 4-5). The contemporary racialization of Muslims in Australia draws heavily upon observable elements of culture. This is a third continuity - that racist incidents still depend on physical features for the selection of victims. For example, anti-Islamic sentiment in Britain is meted out against 'Asians', many of whom may not be Muslim (Modood, 2005: 12). These features are often phenotypical, or based on attire, or the suburb where they live. Hopkins's (2004) interviews with young Muslim Scots revealed that:

young Muslims who visibly display markers of 'Muslimness', whether this be through dress, through having a beard or simply through skin colour, are more likely to be marginalized through everyday racism and lack of access to 
employment than Muslims who do not visibly display their 'Muslimness'. (p. 269)

For example, in Australia, following terror events overseas, hijab-wearing Islamic women have reported higher rates of racist incivilities and attacks than have Islamic men or those women not wearing forms of cover (Dreher, 2005: 11-14, 20-1; Human Rights and Equal Opportunity Commission, 2004). Similarly, the linking of such features to Muslim-ness means that people who are not Muslim (Christian Arabs in Australia) are also subjected to racism as a result of this racialization. Fourth, anti-Muslim racism, and religion-based racialization generally, is by no means remarkable to the current era (Frederickson, 2002). Together these four similarities make anti-Islamic sentiment and actions much like old racism or colour racism - they share functional equivalences (Fredrickson, 2002: 7). ${ }^{3}$

Our view is that there is a conceptual and political clarity in positioning anti-Islamic sentiment and actions as a contemporary form of racialization. What we have described above is the process through which racist attitudes against a group are converted into racist acts. Nonetheless, the process is by no means straightforward, nor is it logical. The conversion of racist attitudes into racist acts does have certain common features, as we have shown. However, that is not to say that the bases of racist attitudes are always the same; sometimes these attitudes are based on notions of 'biological race', although it is nowadays more common to hear racist dispositions that find fault with the culture of a group of people (Dunn et al., 2004). The demarcation between colour/biological/old racism and new/cultural racism has some utility in regard to attitudes. However, the conversion of these attitudes into racist incidents is most simply described as a racialization.

In Australia, there have been generalized complaints about the culture of Islam, constructions applied against all Muslims. These constructions largely ignore the diversity of Australian Muslims, as well as the diversity of Islam world-over. ${ }^{4}$ In the Baulkham Hills case cited above, the municipal mayor was of the view that local residents were justified in being concerned at the development of an Islamic place of worship. At a public meeting, the mayor said he was specifically 'concerned about the girls and ladies in this community', strongly implying that their safety would be endangered by the presence of Muslim men (see Lygo, 2004: 171). Hubbard (2005) noted a similar set of discourses in community opposition to accommodation centres for Muslim asylum seekers in Britain. Opponents of the centres asserted that young women would be unable to walk the streets because of the dangers posed by young Muslim men who were unable to control aggressive sexual tendencies. Hubbard outlined how, in some residents' objections, Muslim men were constructed through themes of animality - of lesser civility and humanity. Again, this is a strong means of suggesting both the incompatibility and lesser status of Muslims. As we 
show in this article, there have also been assertions that Islam does not belong (intimating that Australia is a white/Christian culture). These are mechanisms for the racialization of Islam in Australia.

Opposition to mosque development in Sydney had depended heavily on stereotypes of Islam as fanatical, intolerant, militant, fundamentalist, misogynist and alien (Dunn, 2001). These discourses of opposition also relied upon constructions of who does and does not belong, in the locality and in Australia. The twin arguments of the Baulkham Hills Shire Council against the Islamic centre were that a mosque did not belong in Annangrove, and that there were very few Muslims in the area (Dunn, 2004; O'Rourke, 2003: 3; see also the comments of Council witnesses in Lloyd, 2003: 4). These constructions of non-belonging and absence also depend upon constructions of the 'Self', using narrow articulations of the nation or locality (Dunn, 2003: 160-2; Hage, 1998). Muslim identities in Australia are corralled by this racialization: including discourses of Otherness (threat and inferiority) and fantasies that the Other (in this case Australian Muslims) are absent. In this article, we show how contemporary racism is forcefully operationalized through such grounded debates and disputes. These were not abstract discussions of national identity, belonging and cultural traits. The grounded circumstances include localized moral panics, government and media hostility to asylum seekers, and a security emphasis that implies that Islam is the origin of terrorism. ${ }^{5}$ These provide especially fecund circumstances for the racialization of Islam to thrive.

A good deal has been written about the historic roots of racism in Australia. As a settler colony of Britain, there was a foundational racialization that allowed Britons to dispossess the indigenous peoples of the Australian land mass (Chan et al., 2001). The racialization of Indigenous Australians continues today, and is central to unresolved tensions between black and white Australians (Hamilton, 1990; Royal Commission into Aboriginal Deaths in Custody, 1991). In the latter part of the 1800s, as the white residents of the colonies of Australia considered federating to become a single nation state, there was a surge of racism against non-whites, which was manifest in anti-Asian and anti-Chinese immigration and deportations. One of the first Acts passed in the Australian Federal Parliament was to restrict the entry of Asian migrants; a legislative manifestation of the White Australian policy (Cope et al., 1991: 5). In the post-Second World War era, there was a shift from a 'White Australia' identity and practice towards a phase of Anglo-assimilationism, as more immigrants arrived from European countries other than Britain and Ireland. This draws our attention to hierarchies within white privilege in Australia, and to the presence of an Anglo-Celtic supremacy that mandated the assimilation of non-Anglo Europeans (Greeks, Italians, those from the former Yugoslavia) to the 'Australian way of life'. The latter was code for an Anglo-Australian way of life. Those immigrants who transgressed this assimilation were subject to 
racialization, their culture critiqued as inferior, apart or alien. In the 1980s, as the sources of immigration to Australia expanded beyond Europe to Asia and the Middle East, the new and principal targets of racialization included Vietnamese refugees, Turkish family migrants and Lebanese who had fled the civil war.

In the current era, anti-Islamic sentiment has come to dramatically inflect public debates about national identity, citizenship and belonging. The prominent social commentator and essayist, Robert Manne (2002), observed in The Sydney Morning Herald that 'Islamaphobia now represents the most serious threat to the idea of multiculturalism, and even to the ideas of religious and ethnic toleration, that Australia has witnessed for very many years'. A range of commentators, from quite different political stances, have implied a new and globally dominant racialization axis - Islam and the West. For some conservative commentators, it is a clash of civilizations. ${ }^{6}$ Others have simply made the empirical observation that Muslims in the Islamic world have a racialized view of westerners, and that non-Muslim westerners tend to have a racialized view of Muslims. ${ }^{7}$ Modood (2005: 23) has expressed a fear that this century has the awful potential to develop into a Cold War between Islam and the West, a tension that would be sustained by the racialization we describe in this article. There is a good deal of evidence of such a worrying trend in Australia (Maddox, 2005: 173-84). There are strong and perceptible (racializing) effects of current global politics. The global War on Terror has the potential to construct a racialized binary of the (non-Muslim) West and the Muslim world that will have local effects (Hopkins and Smith, in press). In Australia, the racialization of Muslims is thoroughly influenced by these geopolitical trends. During 2006, the Australian Conservative Prime Minister, John Howard, has repeatedly drawn critical attention to a minority of Muslims who have chosen not to assimilate to 'Australian ways', and who have backward views on the status of women. ${ }^{8}$ The implication, in the context of the global War on Terror, is that this minority is radicalized, or potentially so, and that it presents a security threat. Over the last decade, organized hate groups have reoriented the focus of their campaigns from anti-Asian ${ }^{9}$ to being anti-Muslim (Mason, 2006). The above, then, are the contexts of contemporary racialization in Australia.

\section{SURVEYING CONTEMPORARY RACISM IN AUSTRALIA: PUBLIC ATTITUDES TO ISLAM}

In this article, we draw from three sets of data that demonstrate the attitudinal bases of contemporary racism experienced by Muslims in Australia. These include results from three public opinion surveys as they pertain to 
Muslims, media representations of key Muslim spaces and contemporary discourses about predominantly Muslim asylum seekers:

- The University of New South Wales and Macquarie University Racism Survey, October-December 2001, telephone survey, funded by the Australian Research Council ( $N$ : 5056) (carried out by Dunn, Burnley and Forrest);

- The Port Augusta Questionnaire Survey on Asylum Seekers, June-October 2001, postal survey, funded by The University of New South Wales ( $N: 400$ ) (carried out by Klocker and Dunn);

- The Attitudes Towards Islam Survey, June 2003, funded by the Australia-Indonesia Institute (N:1311) (carried out by Roy Morgan Research and Dunn).

The data reveal the constructions of Otherness (threat, nefarious, inferiority and non-belonging) that are central components of the contemporary racism faced by Australian Muslims. In this section, we review Australian public opinion on Islam. One of the aims of the Attitudes Towards Islam Survey was to collect data on the extent of community fear of Islam (Islamaphobia), and to identify the forms such fear takes. Forty-one percent of respondents were of the view that Islam posed a minor threat to Australia, and a further 15 percent perceived a major threat. ${ }^{10}$ It is noteworthy that although $736(66 \%)$ respondents had stated that Islam posed a threat of some level, only 255 of these were able to articulate the specific form of this threat. This suggests that there is a strong level of unsupported (and unsubstantiated) fear of Islam. There is then a good deal of low-level community apprehension regarding Islam, and a significant minority who perceive a major threat. Broadly speaking, most comments concerned the military threat posed to Australia by Islam (176 comments), and a second strain of opinion concerned cultural threats (76 comments). The former were dominated by references to terrorism, including many mentions of the Bali bombings in 2002 and the 11 September 2001 terror events in the USA. In these comments, there was often an unquestioned assertion that Muslims are terrorists, although there was also an encouraging level of recognition of the media's role in establishing these perceptions of threat. The perception of an Islamic military threat (including terrorism) has been enhanced in recent decades by the aforementioned geopolitical conflicts, media reporting of those (and reporting on other matters), as well as the actions and statements of western governments. The Islamic Council of New South Wales (ICNSW) (2004) has outlined how the Australian Federal Government's legislative, security and military actions have reinforced this perception of an Islamic military/security threat.

The second theme of threat, cultural threat, pertained specifically to the impact of the Muslim presence within Australia. The single strongest theme 
in this regard was a fear that Islam was taking over Australia, or that Muslims wished to convert non-Muslim Australians, often assuming some degree of compulsion:

Because they are fanatical about establishing an Islamic government, they want to make Australia an Islamic state. (Respondent comment, Attitudes Towards Islam Survey, June, 2003)

The notion of cultural takeover was given some political legitimacy in early 2006 when a prominent member of the Howard Government (Dana Vale, MP) publicly expressed a fear that Australian Muslims' fertility rates ${ }^{11}$ meant that Australia would eventually become an Islamic country, unless 'mainstream' Australians were assisted with child care and other family services (Peatling, 2006: 1).

Respondents commented on how the Islamic presence had already generated changes to the celebration of Christmas in Australia.

Well they've come here and they are pushing their beliefs on us: can't have

Christmas carols in schools, can't have pork in school lunches, and it's all because of them. They should come here and fit in with us. (Respondent comment, Attitudes Towards Islam Survey, June, 2003)

This end-of-Christmas story is an emergent 'urban myth' in Australia, largely sponsored by talkback radio, for which there is little, if any, substantive evidence (Burke, 2003: 3; Lygo, 2004: 156-9; Maddox, 2005: 185-6). These constructions of cultural threat and takeover are typical of the racialization of Islam, with the implication of incompatibility and nefarious cultural traits.

Because of the disrespect of the Moslem young men shown towards Australian women. (Respondent comment, Attitudes Towards Islam Survey, June, 2003)

Between October and December 2001, a telephone survey of 5056 residents of Queensland and NSW was undertaken. The survey was composed of a range of questions intended to gather data on racist attitudes (see Dunn et al., 2004). These included questions on the degree of tolerance of key out-groups and on which cultural groups should not belong in Australia. Just under half of those surveyed (44.9\%) felt able to say that some cultural groups do not fit into Australian society. Those respondents were then asked to identify those groups. The most commonly mentioned groups were Muslims (28\% of mentions) and people from the Middle East (28\% of mentions). Muslims and those from the Middle East were the groups that respondents most thought did not fit into Australian society. Anti-Muslim feeling has been strongly recorded in previous attitude polling in Australia (McAllister and Moore, 1989: 7-11). McAllister and Moore's social distance surveys of the late 1980s indicated that Muslim and Arab Australians were key 'out-groups', just ahead of Asian and Indigenous Australians. This intolerance is thought to be sustained through stereotypes, well outlined in 
qualitative work and media studies by Goodall, Jakubowicz, Hage and Lowe, among others (see Goodall et al., 1994: 61-5; Lowe, 1985; Shboul, 1988). There is then a strong sense of Otherness attached to Islam among many Australians.

A Bogardus type instrument was used to test respondent tolerance of key out-groups. ${ }^{12}$ Respondents were asked if they would be concerned (and if so, how much) if a relative were to marry a Muslim, a Jew, a Christian, an Indigenous Australian or a person of Asian, British or Italian background. Over half of the respondents $(52.8 \%)$ indicated that they would be concerned if a close relative were to marry a Muslim, which was twice the rate recorded for other out groups (Table 2). Within that, almost 15 percent of respondents stated they would be extremely concerned, which was four times the rate of extreme concern expressed regarding the other groups. The encouraging finding is that almost half (46\%) of all respondents would not be concerned at all if a relative were to marry a Muslim. Of course, the disappointing observation is that the level of concern regarding Muslims is well above the other 'out-groups'. Table 2 also shows that women were much more likely to communicate concern regarding Islam. Of the 19

Table 2 Any stated concern regarding inter-marriage, to selected 'outgroups', by gender and age

\begin{tabular}{lcccc}
\hline $\begin{array}{l}\text { Would be concerned if } a \\
\text { relative were to marry } \\
\text { a person of... }\end{array}$ & $\begin{array}{c}\text { Muslim } \\
\text { faith } \\
\%\end{array}$ & $\begin{array}{c}\text { Aboriginal } \\
\text { background } \\
\%\end{array}$ & $\begin{array}{c}\text { Asian } \\
\text { background } \\
\%\end{array}$ & $\begin{array}{c}\text { Jewish } \\
\text { faith } \\
\%\end{array}$ \\
\hline $\begin{array}{l}\text { Age } \\
18 \text { to } 34\end{array}$ & 44.9 & 20.3 & 21.0 & 22.3 \\
35 to 64 & 52.7 & 28.7 & 27.2 & 24.0 \\
$65+$ & 63.7 & 40.6 & 36.7 & 26.7 \\
Gender & & & & \\
$\quad$ Male & 48.9 & 30.7 & 28.5 & 24.1 \\
Female & 55.6 & 27.6 & 26.8 & 24.1 \\
All & 52.8 & 28.9 & 27.5 & 24.1 \\
$n$ & 5056 & 5056 & 5056 & 5056 \\
\hline
\end{tabular}

Notes: Question wording:'In your opinion how concerned would you feel if one of your close relatives were to marry a person of ...'

Chi Square tests of the significance of associations for Age were Muslim ( $p=<.000)$, Aboriginal $(p=<.000)$, Asian $(p=<.000)$ and Jewish $(p=<.026)$; and for Gender were Muslim $(p=<.000)$, Aboriginal $(p=<.021)$, Asian $(p=<.218)$, and Jewish $(p=<.935)$.

Source:The University of New South Wales and Macquarie University Racism Survey, Oct-Dec 2001. 
attitudinal questions asked in that survey, this was the only question where women were more intolerant/racist than men. This suggests that the stereotype of Islamic misogyny is an important component of the racialization of Islam in Australia (see Chafic, 1985: 52). This has also been found in Europe (Dwyer, 1993: 156) and in regard to ethnic 'Others' in general (van Dijk, 1987: 55). The stereotype of misogyny is one of the core means by which Islam is constructed as a nefarious culture, and it also suggests cultural inferiority and backwardness by evoking a perception that Muslim men are generally uncivil to women.

These survey results confirm the findings of other researchers and reports on the extent of Islamaphobia in Australia (Browning et al., 2003: 7-8; Dunn, 2001; Hage, 1991; Islamic Council of New South Wales, 1989; McAllister and Moore, 1989: 7-11). Constructions of Muslims as a threat, inferior to and incompatible with Australian culture are core to the racialization of Islam. Many of these constructions also rely upon a narrow construction of the Australian Self, perhaps as Christian or white, but most certainly as 'not Muslim' (see Dunn, 2001).

\section{MEDIA REPRESENTATIONS OF MUSLIM SPACES: THE CASE OF LAKEMBA}

One of the strong Geographic contributions to 'race' studies has been the demonstration of how the spaces of ethnic 'Others' are important to racialization (Bonnett, 1996). News media involvements in moral panics about certain places are good examples. This has been found with regard to Chinatowns in Australia and in regard to media constructions of recent Indo-Chinese-Australian spaces (Anderson, 1990; Dunn and Mahtani, 2001). The Sydney suburb of Lakemba has become popularly associated with some of the 'ethnic' communities present in the surrounding Local Government Area (LGA) of Bankstown, including the Lebanese communities settled in the area, and, within that, a significant Sunni Muslim community. In 2001, there were 19,538 Muslims resident in Bankstown LGA and a further 15,073 in the contiguous LGA of Canterbury (Australian Bureau of Statistics, 2002). Together, the two LGAs are home to a quarter of all Sydney Muslims, and they comprise over 10 percent of the local populations. Sixty-five percent of the Bankstown LGA Muslims were born in Australia, most of the non-Australian born were from Lebanon (28.8\%) and a further 7.3 percent were born elsewhere in the Middle East (Australian Bureau of Statistics, 2003). The suburb of Lakemba has been a focus of critical media attention in Sydney over the last few years. This has been related to clashes between police and youth (de Freitas, 1997), a series of gang rapes of non-Arab women 
and to police hyper-scrutiny of a local religious leader (the Imam of Lakemba Mosque).

Content analysis of media representations of Lakemba during 2001 was undertaken for the two daily Sydney newspapers. The Sydney Morning Herald $(S M H)$ is the so-called quality daily broadsheet in Sydney and The Daily Telegraph $(D T)$ is the daily tabloid. All articles during 2001 that used the term 'Lakemba' were drawn into a data set for content analysis. In all, 149 articles were collected and assessed for their constructions of place and ethnicity. Manifest counts of key words (such as 'violent', and 'crime'/ 'criminal') were tallied. The overall themes and tenor in each article were also collected for latent assessment. ${ }^{13}$

Figure 1 illustrates the dominant themes of the 149 newspaper articles that made reference to Lakemba. It is immediately evident that the most common themes of the articles were crime and violence. Together with other 'negative' themes (gangs, disadvantage, victims and references to September 11 terror attacks) this constituted 77.2 percent of all articles (Figure 1). Almost 10 percent of the articles had a neutral focus on the

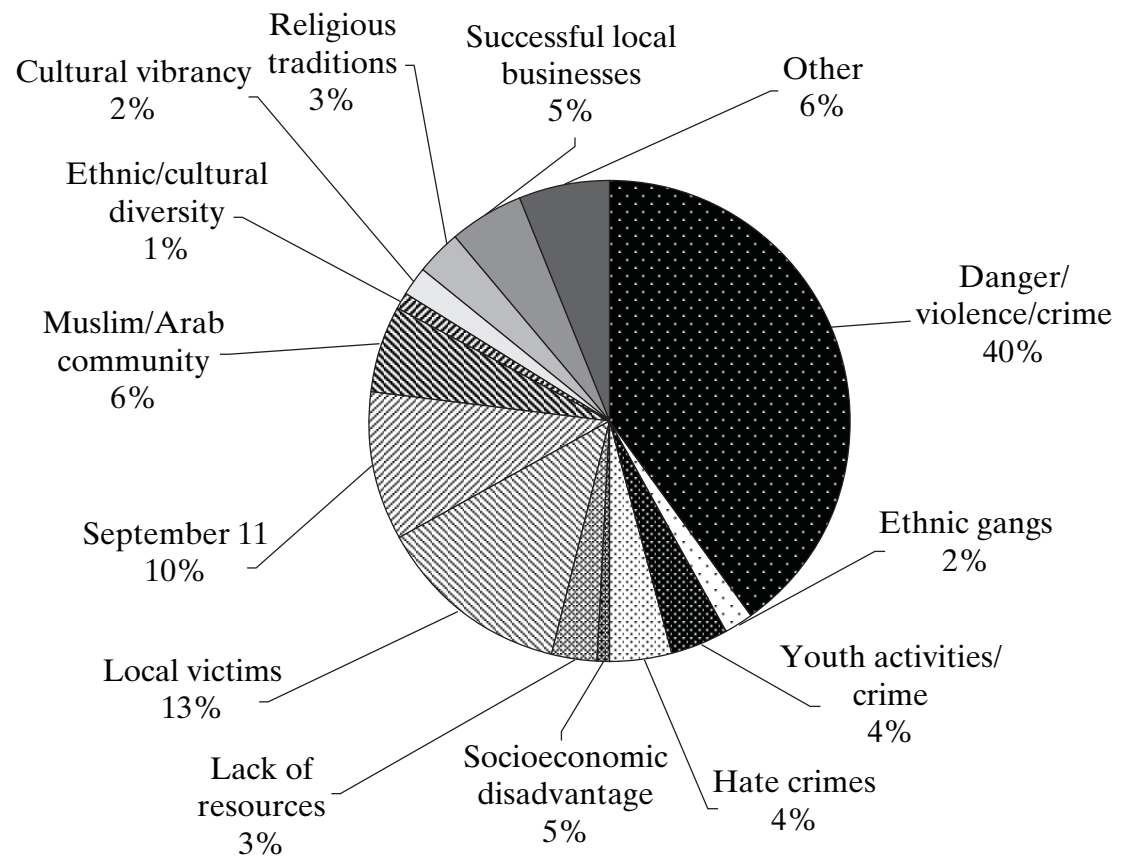

Figure 1 Main theme of Sydney newspaper articles referring to Lakemba, 2001

Source: Latent content analysis of The Sydney Morning Herald, and The Daily Telegraph, 2001 ( $n=149$ articles analyzed). 
local Muslim and Arab communities, or religious traditions and festivals in the area (such as the Eid festivals). Articles with a dominantly celebratory theme were much fewer, with only seven concerning successful businesses or economic opportunity, and only one focusing on the cultural vibrancy of the area. An assessment was also undertaken of the overall tenor of articles towards Lakemba. A handful of the articles were neutral $(11.4 \%)$ and fewer still were mixed (4.7\%). Most articles were overwhelmingly negative in their construction of Lakemba and its Muslim residents $(69.1 \%)$. This corresponds with other analyses of media representations of events and communities in that area of Sydney (de Freitas, 1997; Poynting et al., 2004).

Results of a manifest content analysis support the above findings on tenor and theme. A count was kept of all terms used to describe Lakemba and its residents. Thirty-nine percent of all terms used were ones of crime or criminality and 25 percent were terms of violence. Positive terms, such as law-abiding, peaceful and respectful, each accounted for only 1 percent of all terms used. In all, 64 percent of the articles included a term relating to crime and criminals, and the same proportion contained a term referring to violence. Only 29 percent of articles provided some sense of a context or explanation for crime or social problems in the area, with most articles (71\%) deploying well-rehearsed stereotypes of Islam, relying upon established prejudices among their readers. These data point to an overwhelmingly negative media construction of Lakemba, associating that place and the communities with violence and crime.

A tally was also kept of all references to ethnicity in these newspaper articles. The ethnicity or cultural grouping most often mentioned in the more numerous Daily Telegraph articles was Muslim (28\%), followed by Australian (16\%), Middle Eastern (14\%), then Asian (9\%). Together, Muslim, Middle Eastern and Lebanese comprised 62 percent of all mentions of cultural groupings. These deployments of 'ethnic' labels have a central role in constructing the suburb of Lakemba as inherently Muslim, Lebanese, or Middle Eastern. The label of Australian was used in reference to 'non-ethnics' or Anglo-Australians (see Hage, 1998). This is a core means of reproducing the construction of Anglo-Australians as the Australian, and of non-Anglos as non-Australian (as 'ethnic', or Muslim, etc). The racialized reporting on Lakemba during 2001 constructed it as a place of Muslims and people from the Middle East, and as a place of violence and crime. It also associated Lakemba with terror events in September of that year. The media depiction of Lakemba has been part of a racialization process identified elsewhere, in which Muslims are constructed as fanatical, intolerant, militant, fundamentalist, misogynist and alien (Dunn, 2001). This has been a very strong mechanism in Australia for reproducing discourses of Islam as a threat and as nefarious. 


\section{MEDIA AND FEDERAL GOVERNMENT CONSTRUCTIONS OF ISLAMIC ASYLUM SEEKERS}

Between mid-2001 and early 2002, we collected data on the portrayal of asylum seekers by the Australian Federal Government and sections of the print media. The work also involved a survey of public opinion in the South Australian provincial city of Port Augusta. The study period was characterized by the prominence of asylum seeker issues in Australian public debate at the time. It encompassed the so-called 'Tampa incident' (when the Australian Navy were ordered by the Conservative Government to intercept a merchant ship that was carrying rescued asylum seekers towards an Australian port), the September 11 terror attacks, a Federal Election, the drowning of asylum seekers en-route to Australia, and claims that other asylum seekers had thrown their children overboard to pressure Australian naval personnel to take them on board (later found to be untrue). Many of the sea-borne asylum seekers attempting to reach Australia, during this period and before it, were from Muslim countries. The already heated issues of immigration and border control were inflamed by an Islamaphobia that had been accumulating a greater intensity. Asylum seekers have been found to be targets of quite extreme hostility in the West in the late 1990s and early 2000s. For example, the Australian Survey of Social Attitudes (2004) found that 70 percent of Australians believed the Federal Government should take a stronger stance against 'illegal immigrants'. Pedersen et al.'s (2005; 2006) reviews of the Australian evidence, and their own social psychology surveys in Western Australia, revealed a particularly strong antipathy towards asylum seekers in Australia since the late 1990s. Empirical findings on European attitudes are similar. The European Commission's (1997: 7) Eurobarometer survey of attitudes found that 66 percent of respondents wanted all 'illegal immigrants' repatriated. Schuster (2003) outlined how the dominant representations of asylum seekers in Europe too easily carry over the racializations imposed upon those people by the persecuting governments and people they are fleeing. Across Europe, this poor portrayal has laid a basis for intolerance and for actions of dispersal, detention and deportation.

The intention of Klocker and Dunn's (2003) research was an intertextual analysis of how one set of discourses influenced others (e.g. government upon media, media upon public opinion). All Federal Government statements on refugees and asylum seekers during the six-month study period were analysed for their content, tenor and context (56 statements). The same analytical frame was applied to articles regarding asylum seekers in two metropolitan newspapers (The Adelaide Advertiser and its Sunday stable mate The Sunday Mail) and one local newspaper (The Transcontinental in Port Augusta) (491 articles in total). Port Augusta was 
selected as a site for analysing public opinion because of its proximity to the desert-based Woomera Immigration Reception and Processing Centre (IRPC) and the even closer and newly built Baxter IRPC. Questionnaires were mailed to a random sample of 1000 Port Augusta residents and 400 valid completions were returned.

In the final days of the November 2001 Federal Election campaign, the Conservative Prime Minister, John Howard, repeatedly proclaimed 'we will decide who comes to this country and the circumstances in which they come'. This slogan became a key rhetorical device in the conservative's campaign for re-election, appearing on election posters and other campaign materials (Jupp, 2002: 199; Marr and Wilkinson, 2003: 245-6, 277). Asylum seekers were transformed into a 'law and order' issue and were accordingly portrayed as a threat to Australia's border integrity and sovereignty. The Government latched on to the false reports that asylum seekers had threatened to throw their children overboard, despite the fact that these reports were very quickly revealed as inaccurate. ${ }^{14}$ The Prime Minister announced 'I don't want people like that in Australia' (see Maddox, 2005: 166-192; Marr and Wilkinson, 2003: 189). Furthermore, the Federal Government mandated that public relations officers within the military and immigration department should not release any images that served to humanize asylum seekers, and various cabinet ministers made direct links between asylum seekers and the threat of terrorism (Klocker and Dunn, 2003; Marr and Wilkinson, 2003: 280-1). Some MPs even asserted that the Taliban may have been smuggling in terrorists in the guise of asylum seekers (Slipper, quoted in Papps, 2001: 14). ${ }^{15}$ Asylum seekers were purposefully constructed by the Government as less (than) human, terror threats. Maddox (2005: 179) observed that it was 'the latest twist in the line of inference and allusion which linked Muslims, suburban teenage criminals, international terrorists, fundamentalist theocrats and desperate asylum seekers as "Them".

Content analysis revealed that Federal Government statements were overwhelmingly and consistently negative (90.9\%), with only three (out of 56 statements, $5 \%$ ) coded as having a positive tenor towards asylum seekers (Klocker and Dunn, 2003). The most common constructions of asylum seekers in Government statements were illegitimacy $(22.8 \%$ of terms tallied), followed by illegality $(18.0 \%)$ and threat $(16.3 \%)$. Moreover, the Government clearly flagged the ethnicity of these threatening and undesirable asylum seekers. The most regularly mentioned cultural grouping in the Government statements analysed were Pakistani $(28 \%)$, then Afghan (26\%), followed by Middle Eastern (7\%), Iraqi (7\%) and Sri Lankan (7\%). The racializing discourse drew upon, and reinforced, stereotypes of the alien, threatening and violent Muslim. There were also overt evocations of the 'Self' in these statements. Each Government statement also contained at least one reference (on average) to the unspecified self: as 'Australians', and 'our territory/borders, etc'. These references to the Self 
(non-ethnicized, but Anglo) served to complete the binary with the Muslim Other who were seeking asylum.

The tenor of the newspapers examined was a little more likely to be positive towards asylum seekers, with The Advertiser articles the most sympathetic (18.5\% positive), and The Sunday Mail $(9.2 \%)$ and The Transcontinental (9.5\%) much less so. However, the most frequently used terms to describe asylum seekers in the three newspapers were still those in the 'threat' category of description. Constructions of asylum seekers as the Other were also prominent. All three newspapers actively dehumanized asylum seekers, with 'detainee' and 'boat people' being the most frequently used terms within this 'Other' category of description. Extreme quotations, such as that from the Mayor of Port Augusta - 'those bastards can run like camels if they escape' (Baluch, quoted in Maiden and Duffy, 2002: 5) served to accentuate dehumanization. Examples of threatening representations of asylum seekers from the three newspapers included:

Residents' safety has been a concern and an issue, especially when a riot at the centre led to a large number of detainees escaping and making their way into the town [Woomera]. (Gerlach, 2001)

The violent behaviour of some detainees in a bid to get their own way has been appalling with buildings burnt, guards attacked and claims children have been forced to have their lips sewn together. (Crouch, 2002)

Special Air Service troops conducted covert surveillance of a man believed to be a 'sleeper agent' with connections to Osama bin Laden. SAS troops installed a miniature camera in the asylum seekers' sleeping quarters to watch over the suspected terrorist. (Advertiser, 2001)

Klocker and Dunn (2003) concluded that the negative media representations of asylum seekers had depended heavily upon, if not been directed by, the representations deployed within Federal Government discourse. As in the Government documents, representations of ethnicity within the newspaper articles associated asylum seekers, and the negativity directed at them, with the Muslim Other. The main ethnicity references in The Adelaide Advertiser were to Afghanis (36\%), Iraqis (20\%), Middle Easterners (7\%), Muslims (5\%), Iranians (10\%) and Sri Lankans (4\%), and references in the Sunday version of the paper were even more dominated by the first four of those cultural groupings. As with Government statements, there were always references to the Self, as: 'Aussies', the 'Australian people', 'Australian society' and, in the case of The Transcontinental, to 'locals' and 'residents'. These references served to reinforce a definitional divide between the resident (Anglo/non-Muslim) Self, and the threatening asylum seeking Other.

Public opinion, as measured through a questionnaire survey in Port Augusta, was also potently negative in regard to asylum seekers. When asked to select terms representing their opinions of asylum seekers from a list provided, respondents overwhelmingly selected very negative 
descriptors. Table 3 provides a further sense of the key constructions of asylum seekers selected by questionnaire respondents. Three-quarters of all respondents pointed to the threat that asylum seekers posed to Australian borders and security, and more than six out of 10 identified the issue as a national crisis. Clearly, public opinion on asylum seekers, broadly constructed as Muslims, was of an Other who were a threat to national security and integrity.

Of the 400 respondents, 113 made an unsolicited link between asylum seekers and Islam within open responses and margin annotations to the questionnaire. The comments were overwhelmingly negative and focused on the problems with Muslims or with Arabic asylum seekers. A third of these comments centred on the perceived violence, fanaticism and terrorism that respondents associated with asylum seekers (see Figure 2). These concerns draw directly from the stereotype of the Muslim fanatic (Dunn, 2001). A further 38 percent of such comments asserted that the cultures of these asylum seekers were too different from the 'Australian way of life', and 15 percent worried that asylum seekers would cause 'cultural problems' in Australian society. Together, these two forms of response demonstrate the racialization of Islam. Muslim asylum seekers were constructed as possessing inferior cultural traits, particularly as judged against a narrowly defined national cultural norm. Respondents' written comments on asylum

Table 3 Terms selected by survey respondents as representative of asylum seekers, Port Augusta, 2002

\begin{tabular}{|c|c|c|c|c|}
\hline Term/phrase & $\begin{array}{c}\text { Yes } \\
\text { (no.) \% }\end{array}$ & $\begin{array}{l}\text { No } \\
\text { (no.) } \%\end{array}$ & $\begin{array}{l}\text { No opinion } \\
\text { (no.) } \%\end{array}$ & $\begin{array}{l}\text { No response } \\
\text { (no.) } \%\end{array}$ \\
\hline Flood & (171) 42.8 & (136) 34.0 & (48) 12.0 & (45) 11.3 \\
\hline Crisis & (254) 63.5 & (78) 19.5 & (29) 7.3 & (39) 9.8 \\
\hline Invasion & (208) 52.0 & (136) 34.0 & (23) 5.8 & (33) 8.3 \\
\hline Disorderly & (300) 75.0 & (47) 11.8 & (15) 3.8 & (38) 9.5 \\
\hline Trickle & (80) 20.0 & (222) 55.5 & (43) 10.8 & (55) 13.8 \\
\hline Manageable & 27.3 & (212) 53.0 & (28) 7.0 & (51) 12.8 \\
\hline $\begin{array}{l}\text { Small by international } \\
\text { standards }\end{array}$ & (139) 34.8 & (151) 37.8 & (53) 13.3 & (57) 14.3 \\
\hline $\begin{array}{l}\text { Threat to integrity of } \\
\text { Australia's borders }\end{array}$ & (294) 73.5 & (62) 15.5 & (15) 3.8 & (29) 7.3 \\
\hline Threat to Australia's security & (306) 76.5 & (55) 13.8 & (16) 4.0 & (23) 5.8 \\
\hline
\end{tabular}

Source: The Port Augusta Questionnaire Survey on Asylum Seekers, Jun-Oct 2001, questionnaire responses to Question 2 'Which of the following terms and phrases do YOU think describe the arrival of asylum seekers by boat in Australia? Please tick a response for EVERY term or phrase'. 


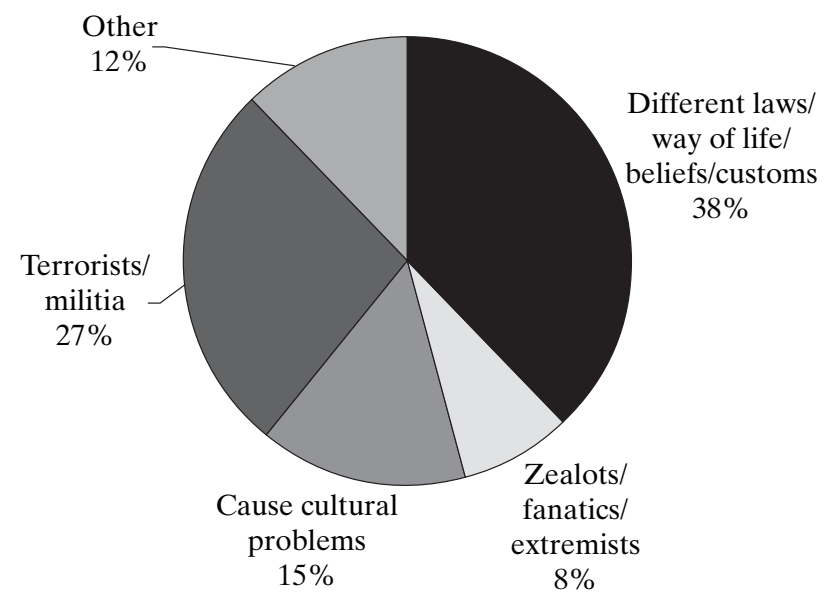

Figure 2 Respondent comments on the culture of asylum seekers, Port Augusta, 2002

Source: The Port Augusta Questionnaire Survey on Asylum Seekers, Jun-Oct 2001. Manifest coding of questionnaire open responses and respondent annotations (where $n=113$ respondents made unsolicited comments on Islam, from the 400 valid returned surveys).

seekers were hypercritical of their culture and exemplified these contemporary forms of racism:

I don't want people who might blow themselves or others up living near me ... If these people really want to live like Australians in a free country, they should learn to leave some of their customs, beliefs and religion behind them. Why is it that Australians always have to accept everyone else's cultural beliefs but they do not accept our ways, or our beliefs. People from some of these countries do not live like people in Australia. Women to them are second-class and women in Australia are educated and have some, if not all, equal rights in employment etc. (Respondent no. 171, Port Augusta Questionnaire Survey on Asylum Seekers, 2001)

Some respondent comments were vitriolic, and incited racist violence:

On Federal land, the government should use real ammunition to gain respect and send the rag heads home to their own country.... The Navy should blow them out of the water. Sharks and sea lice would clean up. (Respondent no. 128, Port Augusta Questionnaire Survey on Asylum Seekers, 2001)

Being close to the camp means that some will wander our streets so I will be able to spit on and abuse them. ... I can hardly wait. (Respondent no. 282, Port Augusta Questionnaire Survey on Asylum Seekers, 2001)

Asylum seekers to Australia in recent years have borne the brunt of government-reinforced, if not endorsed, hostility. The tenor and theme of 
media treatment has largely reflected the negative disposition of official government statements. Islamic asylum seekers have been constructed as less (than) human, incompatible and threatening, and considered deserving of inhumane treatment. Government and media discourses regarding asylum seekers have been a key means of racialization.

\section{THE RACIALIZATION OF ISLAM IN AUSTRALIA}

The three data sets outlined above point to the generally poor public perception of Islam in Australia. This antipathy is reinforced by problematic media treatment and a hostile government disposition. The negativity has material impacts upon Australian Muslims. Such constructions (mis)inform opposition to mosque development (Dunn, 2001, 2003), and lie behind arson attacks and racist violence (Human Rights and Equal Opportunity Commission, 2004). During 2003, the Racism Monitor collected data from community organizations on the experience of racism and found that acts of discrimination, verbal abuse and violence were commonplace for Australian Muslims (Browning et al., 2003). Such incivility was so widespread that Islamic organizations had come to see it as an 'ordinary experience' of Australian life. An Islamic community representative was quoted: 'it happens so often and goes unnoticed, therefore we have learnt to accept this sort of bad behaviour' (quoted in Browning et al., 2003: 7). Muslims in the West almost unanimously point to the unreasonableness and defamatory effect of media portrayals of Islam. This is a recurring theme of any contemporary ethnographic work with Muslims in western countries, including the UK and Australia (Dreher, 2005: 23; Hopkins, 2004: 268-9).

Muslim identities in Australia are corralled by racialization. The accumulating western stereotypes of Islam - a mix of the now well-known stereotypes of fanaticism, violence, misogyny and general incivility (animality) swirl within local debates about mosques and in the racialization of certain suburbs, and in security and asylum seeker discourses. Muslims are constructed as culturally inferior or incompatible with non-Muslim 'Australian' culture - as culturally Other. Certain spaces (such as the suburb of Lakemba) and flows (asylum seekers) are the terrains in which racialization is grounded and reproduced. These representations also depend upon narrow constructions of the Self, supported by a desire that the Other (in this case, Muslims) be absent from the national space. Our argument, influenced by Modood (2005: 11, 17), is that this is usefully conceptualized as a racialization of Islam. The racism faced by Australian Muslims is not a new phenomenon per se; it relies upon asserted inherentisms, and it reinforces cultural hierarchies and privilege. Anti-Islamic sentiment is not a biological racism; such antipathy is rather culturally directed. This justifies the 
retention of a distinction between colour and cultural racism, although our argument is that both types of racist attitude are operationalized into racist acts in essentially similar ways, through a racialization. In the contemporary context of terror events by extremists and the global War on Terror (including the West's occupation of Iraq), this racialization generates local and palpable experiences of racist abuse, violence and exclusion for western Muslims. These experiences have been extended, following new terror events or 'western' responses (Dreher, 2005: 25). These racist acts against Australian Muslims rely upon certain markers of culture. This is a racialization process, but without 'race'.

What we have outlined above are key instruments and rhetoric of the racialization of Islam in Australia. These Islamic identities contain or imprison Muslim Australians to a circumstance of lesser citizenship. The ICNSW (Islamic Council of New South Wales, 2004) referred to this as an experience of marginalization. This racialization has corralled Muslim identity and citizenship. Of course, Australian Muslims contest this confinement. Organizations such as the ICNSW, and some local mosque associations, have attempted to assert alternative constructions, to speak against damaging portrayals, and to reach out to local non-Muslims. These organizations face an exceptionally difficult task, made all the more difficult by the frequency and reach of contemporary racialization. Australian Islamic organizations have nonetheless remained positive, constructive and hopeful. Indeed, Muslims in the West may be an essential key to contesting this racialization and confounding the emergence of an Islam/West divide (Manji, 2004). Hopkins (2004: 268-9) made reference to three sets of remedy: changing the racialization of Islam through the media, improving public understandings of Islam, and specifically, expanding public recognition in the West of Islamic heterogeneity. We implied earlier that some sections of the media maintain a critical perspective on Government statements and actions regarding Islam, and (some) public opinion retains a healthy cynicism regarding both media and Government. These are a healthy basis upon which to progress the first form of remedy. Drawing attention to the cultural and religious heterogeneity of Australian Islam, as described earlier, would also help to confound the 'inherentism' or static generalizations that are core to racialization. These ruptures against racialization, and potentials, are the sources of hope. Finally, racialization constructs both the Other and the Self, and so expanding popular understandings of Australian-ness beyond Anglo-Celtic/Christianity is fundamentally important.

\section{Notes}

1 Muslims in Australia are very urbanized. Indeed, almost half (47.8\%) of all Australian Muslims reside within Sydney $(134,366)$, constituting 3.4 percent of 
the Sydney population. The presence of Muslims is particularly significant in the capital cities, especially Sydney and Melbourne. There has been a substantive presence since the Turkish and Lebanese migration flows of the 1970s, and the number of Australian Muslims has been doubling every ten years.

2 The existing residential building was the target of vandalism and offensive graffiti, the latter daubed on the inside and outside of the structure while the case was under appeal. Later (June, 2004), a racialized attack on the property included the placing of pigs' heads on stakes, and the smearing of pig offal throughout the site.

3 While Frederickson made this important comment on functional equivalence, it should be noted he nonetheless prefers a conceptual distinction between racism and religious intolerance. His argument is that the former (based around 'race') proscribes change and integration between peoples, whereas the latter is based upon a desire for integration.

4 Often these criticisms of Muslims are conflated with criticisms of ArabAustralians, there is a regular conflation of the two within public discourse (see Human Rights and Equal Opportunity Commission, 2004; Poynting et al., 2004).

5 Australian Government parliamentarians and Ministers have simplistically associated terrorism with Islam. They have commonly used conjunctions of the term 'Islamic' with 'terrorist', 'fanatic' or 'militant' to describe protagonists within Muslim countries. Take for example, the following statement from Foreign Minister Downer (2004: 18): 'The fundamentalist Islamic extremist terrorists (or Islamo-facists) cannot achieve their aims through ....

6 US President George W. Bush's reference to the new 'War on Terror' as a crusade fed this rhetoric of an Islam-West axis (Walker, 2001 cited in Maddox, 2005: 173-4, 345). The leader of the Catholic Church in Australia, Cardinal Pell, has provocatively used precisely the rhetoric of the Cold War to describe an inherent tension he perceives between Islam and Christianity (Islamic Council of New South Wales, 2005; Zwartz, 2004: 3). Cardinal Pell (2004: 17) made a direct analogy between Islam and communism, and implied that Islam could be an intolerant and dark political substitute for the emptiness of secular democracy.

7 The Pew Global Attitudes Project surveyed 14,030 people in 13 countries, between March and May 2006, to gather data on a range of attitudes, including perceptions of Westerners and Muslims. Muslims in Islamic countries saw the West as the cause of geopolitical instability and perceived westerners as immoral, greedy and selfish. Non-Muslims in the West saw Muslims as a threat, and as disrespectful of women (Pew Research Centre, 2006: 13-17).

8 The Australian Prime Minister, John Howard, referred in February to his 'longheld' concern about some Australian Muslims who kept on 'raving about jihad', and the conservative attitudes towards women (Kerbaj and Megalogenis, 2006: 3 ). These concerns were repeated in August on Macquarie radio, along with concerns about a lack of English language competency among migrants generally and a perception that some Muslims were not integrating well enough. In the same period, the Federal Attorney General expressed his disdain at a lack of tolerance among some Muslims (Kerbaj, 2006: 4).

9 It should be noted that in the Australian circumstance, 'Asian' in everyday speech usually refers to people with ancestries to East Asia, including 
north-east Asia (e.g. China, Japan, Hong Kong) and south-east Asia (e.g. Vietnam, Thailand). This is different from the British usage, where 'Asia' would normally refer to Pakistan and India.

10 Asking respondents for their opinions on the threat that Islam poses to Australia was itself likely to stimulate an articulation of a perceived threat. That 36 percent of respondents perceived no threat (and a further 6 percent did not feel able to comment) could be seen as an encouraging indicator that Australians are by no means universally convulsed with Islamaphobia.

11 There is little evidence that fertility rates among Australian Muslims are structurally different from other Australians. In general, fertility rates of migrants in Australia tend to quickly approximate the average, certainly within a generation (Burnley, 2001). Furthermore, fertility rates in most Muslim countries are also low, by historical standards, e.g. total fertility rates of 2.2 in Lebanon and 2.02 in Iran.

12 The 'out-groups' analysed were selected, based on previous attitudinal survey research and critical cultural studies work. The survey also included some nonout-groups to test for variation, these included Christians and Australians of an Italian and British background.

13 The content of the two newspapers varied in interesting ways, on some of the issues. However, there is not space here to interpret those variations (see Salabay, 2002).

14 The Federal Government failed to reveal this falsity to the public until many months after the federal election (Commonwealth of Australia, 2002).

15 The Edmund Rice Centre for Justice and Community Education (2002) made the useful observation that only one out of 13,000 asylum seekers to Australia in 2001 was actually deemed a security threat.

\section{References}

Advertiser (2001) 'Exclusive: Boat People Abused Manoora Crew: Bites, Filth and Threats', The Advertiser, 13 October, p. 1.

Anderson, K.J. (1990) "“Chinatown Re-oriented”: A Critical Analysis of recent Redevelopment Schemes in a Melbourne and Sydney Enclave', Australian Geographical Studies 28(2): 137-54.

Australian Bureau of Statistics (2002) 'Census of Population and Housing', Australian Bureau of Statistics CD Package, CDATA2001, Canberra.

Australian Bureau of Statistics (2003) Customised Matrix: Islam by Birthplace. Sydney: Australian Bureau of Statistics.

Australian Survey of Social Attitudes (2004) 'Australian Survey of Social Attitudes', Research School of Social Sciences, Australian National University [http: //assda224-100.anu.edu.au].

Barker, M. (1981) The New Racism: Conservatives and the Ideology of the Tribe. London: Junction Books.

Blum, L.A. (2002) I'm Not a Racist, But . . .: The Moral Quandary of Race. New York: Cornell University Press.

Bonnett, A. (1996) 'Constructions of 'Race', Place and Discipline: Geographies of 'Racial' Identity and Racism', Ethnic and Racial Studies 19(4): 864-83. 
Browning, J., A. Jakubowicz and A. Gold (2003) 'What Can We Say about Racism in Australia?' Discussion Paper No. 1, Racism Monitor, July.

Burke, K. (2003) 'No Need to Take Christ out of Christmas, Say Other Religions', The Sydney Morning Herald, 15 December, p. 3.

Chafic, W. (1985) 'Muslim Women in Australia', in New South Wales Anti-Discrimination Board (ed.) Islam in Australia, pp. 48-54, Sydney: New South Wales AntiDiscrimination Board.

Chan, H., A. Curthoys and N. Chiang (eds) (2001) Proceedings of the Overseas Chinese in Australasia: History, Settlement and Interactions. Taipei: Interdisciplinary Group for Australasian Studies (IGAS) and Centre for the Study of the Chinese Southern Diaspora.

Cole, J. (1997) The New Racism in Europe. Cambridge: Cambridge University Press.

Commonwealth of Australia (2002) Report of the Senate Select Committee on a Certain Maritime Incident (Children Overboard Inquiry). Canberra: Senate Select Committee, Parliament House.

Cope, B., S. Castles and M. Kalantzis (1991) Immigration, Ethnic Conflicts and Social Cohesion. Canberra: Bureau of Immigration Research, Australian Government Publishing Service.

Crouch B. (2002) 'Desert Cloud over our Day', The Sunday Mail, 27 January, p. 35.

de Freitas, F. (1997) 'The "Belmore Riot": Ethnic violence or media beatup?', Reportage, Spring: 43-5.

Downer, A. (2004) 'Facing a War of Ideals We Must Win', The Adelaide Advertiser, 16 April, p. 18.

Dreher, T. (2005) Targeted: Experiences of Racism in NSW after September 11, 2001. Ultimo: University of Technology Sydney Press.

Dunn, K.M. (2001) 'Representations of Islam in the Politics of Mosque Development in Sydney', Tijdschrift voor Economische en Sociale Geografie 92(3): 291-308.

Dunn, K.M. (2003) 'Using Cultural Geography to Engage Contested Constructions of Ethnicity and Citizenship in Sydney', Social and Cultural Geography 4(2): 153-65.

Dunn, K.M. (2004) 'Islam in Australia: Contesting the Discourses of Absence', The Australian Geographer 35(3): 333-53.

Dunn, K.M. and M. Mahtani (2001) 'Media Representations of Ethnic Minorities', Progress in Planning 55(3): 163-72.

Dunn, K.M., J. Forrest, I. Burnley and A. McDonald (2004) 'Constructing Racism in Australia', Australian Journal of Social Issues 39(4): 409-30.

Dwyer, C. (1993) 'Constructions of Muslim Identity and the Contesting of Power: The Debate over Muslim Schools in the UK', in P. Jackson and J. Penrose (eds) Constructions of Race, Place and Nation, pp. 143-59. London: University College London Press.

Edmund Rice Centre for Justice and Community Education (2002) 'Debunking the Myths about Asylum Seekers', in J. Healey (ed.) Australia's Immigration Debate: Issues in Society, pp. 29-31. Rozelle: The Spinney Press.

European Commission (1997) Racism and Xenophobia in Europe. Eurobarometer Opinion Poll No. 47.1. Brussels: European Commission, Employment, Industrial Relations and Social Affairs Directorate. 
Fredrickson, G.M. (2002) Racism: A Short History. Princeton, NJ: Princeton University Press.

Gilroy, P. (1987) There Ain't No Black in the Union Jack: The Cultural Politics of Race and Nation. London: Hutchinson.

Gerlach, C. (2001) 'Detention Centre - What's Happened in Woomera', The Transcontinental, 5 September, p.5.

Goodall, H., A. Jakubowicz, J. Martin, T. Mitchell, L Randall and K. Seneviratne (1994) Racism, Ethnicity and the Media. St Leonards: Allen \& Unwin.

Hage, G. (1998) White Nation: Fantasies of White Supremacy in a Multicultural Society. Annandale: Pluto Press.

Hall, S. (1992) 'New Ethnicities', in J. Donald and A. Rattansi (eds) 'Race', Culture and Difference, pp. 252-9. London: Sage.

Hamilton, A. (1990) 'Fear and Desire: Aborigines, Asians and the National Imaginary', Australian Cultural History 9: 14-35.

Hopkins, P. (2004) 'Young Muslim men in Scotland: Inclusions and Exclusions', Children's Geographies 2(2): 257-72.

Hopkins, P. and S. Smith (in press) 'Scaling segregation; racialising fear', in R. Pain and S.J. Smith (eds) Fear: Critical Geopolitics and Everyday Life. Aldershot: Ashgate.

Hubbard, P. (2005) 'Accommodating Otherness: Anti-asylum Centre Protest and the Maintenance of White Privilege', Transactions of the Institute of British Geographers 30: 52-65.

Human Rights and Equal Opportunity Commission (2004) Ismaع Listen: National Consultations on Eliminating Prejudice Against Arab and Muslim Australians. Sydney: Human Rights and Equal Opportunity Commission (HREOC).

Islamic Council of New South Wales (1989) 'Submission to the Human Rights and Equal Opportunity Commission Inquiry into Racist Violence', Submission no. 4.28, Islamic Council of New South Wales, Zetland.

Islamic Council of New South Wales (2004) 'Challenges for Australian Muslims: Discrimination, Anti-Terrorism, and the Media, Islamic Council of New South Wales', Islamic Council of New South Wales, Chullora.

Islamic Council of New South Wales (2005) 'A Response to Cardinal Pell's Crusade against Islam', Islamic Council of New South Wales, Chullora.

Jayasuriya, L. (2002) 'Understanding Australian Racism', Australian Universities Review 45(1): 40-4.

Jupp, J. (2002) From White Australia to Woomera: The Story of Australian Immigration. Cambridge: Cambridge University Press.

Kerbaj, R. (2006) 'Ruddick's Call for Behaviour Angers Muslims on Holy Day', The Australian, 11 January, p. 4.

Kerbaj, R. and G. Megalogenis (2006) 'PM Accused over Jihad Remark', The Australian, 21 February, p. 3.

Klocker, N. and K.M. Dunn (2003) 'Who's Driving the Asylum Debate? Newspaper and Government Representations of Asylum Seekers', Media International Australia 109: 71-92.

Kobayashi, A. and L. Peake (2000) 'Racism Out of Place: Thoughts on Whiteness and an Antiracist Geography in the New Millennium', Annals of the Association of American Geographers 90(2): 392-403.

Lloyd, J. (2003) New Century Developments P/L v. Baulkham Hills Shire Council 
[2003], New South Wales Land and Environment Court, 154, reported decision 127 LGERA 303, 5 September.

Lowe, B. (1985) 'Islam and the Media', in New South Wales Anti-Discrimination Board (ed.) Islam in Australia, pp. 55-62, Sydney: New South Wales AntiDiscrimination Board.

Lygo, I. (2004) News Overboard: The Tabloid Media, Race Politics and Islam. Sydney: Southerly Change Media.

Maddox, M. (2005) God Under Howard: The Rise of the Religious Right in Australian Politics. Crows Nest: Allen and Unwin.

Maiden, S. and M. Duffy (2002) 'Teenager in Failed Hanging Attempt', The Adelaide Advertiser, 30 January, p. 5.

Manji, I. (2004) The Trouble with Islam: A Muslim's Call for Reform in Her Faith. Random House, Sydney.

Manne, R. (2002) 'Open Season on Muslims in the Newest Phobia', The Sydney Morning Herald, 16 September, $\mathrm{p} 13$.

Marr, D. and M. Wilkinson (2003) Dark Victory. Crows Nest: Allen and Unwin.

Mason, G. (2006) 'Hating through the Language of Care', Workshop: Free Speech, Hate Speech and Human Rights in Australia, The Academy of Social Sciences in Australia, Australian National University, 8-9 September, Canberra.

McAllister, I. and R, Moore (1989) Ethnic Prejudice in Australian Society: Patterns, Intensity and Explanations. Canberra: Office of Multicultural Affairs.

Modood, T. (2005) Multicultural Politics: Racism, Ethnicity and Muslims in Britain. Minneapolis, MN and Edinburgh: University of Minnesota Press and University of Edinburgh Press.

O'Rourke, C. (2003) 'Muslim Center Won't Fit In, Court Told', The Sydney Morning Herald, 13 May, p. 3.

Papps, N. (2001) 'After 30 Days at Sea the First Dejected Asylum Seekers from the Manoora Set Foot on Nauru to Cheers and Claps: Land at Last - with Garbage Bags of Hope', The Advertiser, 20 September, p. 14.

Peach, C. (2006) 'Muslims in the 2001 Census of England and Wales: Gender and Economic Disadvantage', Ethnic and Racial Studies 29(4): 629-55.

Peatling, S (2006) 'Abortion Will Lead to Muslim Nation: MP', The Sydney Morning Herald, 14 February, p. 1.

Pedersen, A., J. Attwell and D Heveli (2005) 'Prediction of Negative Attitudes toward Australian Asylum Seekers: False Beliefs, Nationalism and Self-esteem', Australian Journal of Psychology 57, 148-60.

Pedersen, A., S. Clarke, P. Dudgeon and B. Griffiths (2005) 'Attitudes toward Indigenous-Australians and Asylum-seekers: The Role of False Beliefs and other Social-Psychological Variables', Australian Psychologist 40(3): 170-8.

Pell, G. (2004) 'Towards a Transformative Democracy Founded on the Dignity of Us All', The Sydney Morning Herald, 12 November, p. 17.

Pew Research Centre (2006) 'Europe's Muslims More Moderate: The Great Divide: How Westerners and Muslims View Each Other', The Pew Global Attitudes Project, Washington, DC.

Poynting, S., G. Noble, P. Tabar and J. Collins (2004) Bin Laden in the Suburbs: Criminalising the Arab Other. Sydney: Sydney Institute of Criminology.

Royal Commission into Aboriginal Deaths in Custody (1991) National Report Volume 2: The Underlying Issues Which Explain the Disproportionate Number of 
Aboriginal People in Custody. Canberra: Australian Government Publishing Service.

Salabay, T. (2002) 'The Media Representation of Lakemba, Sydney: Constructions of Place and Methods of Resistance', unpublished honours thesis, Geography Program, University of New South Wales, Australia.

Schuster, L. (2003) 'Common Sense or Racism? The Treatment of Asylum Seekers in Europe', Patterns of Prejudice 37(3): 234-55.

Shboul, A. (1988) 'Islam and the Australian Media: The Implications of Distorting Mirrors', Australian Religious Studies Review 1(2): 18-23.

van Dijk, T.A. (1987) Communicating Racism: Ethnic Prejudice in Thought and Talk. Newbury Park, CA: Sage.

Zwartz, B. (2004) 'Islam could be New Communism, Pell tells US Audience', The Sydney Morning Herald, 12 November, p. 3.

KEVIN M. DUNN is Associate Professor in BEES at the University of New South Wales. Address: School of BEES, UNSW Sydney, NSW 2052, Australia. [email:k.dunn@unsw.edu.au]

NATASCHA KLOCKER is a PhD student in BEES at the University of New South Wales. Address: School of BEES, UNSW Sydney, NSW 2052, Australia. [email:n_klocker@hotmail.com].

TANYA SALABAY is a graduate student in the School of International and Political Studies at Deakin University, Australia. Address: 152 Romcek 4, Rattanak Commune, Battambang, Cambodia. [email: tanya_salabay@hotmail.com] 